\title{
HISTORICAL FORMS OF ETHNIC IDENTITY IN THE CONTEXT OF THE DEVELOPMENT OF CONTEMPORARY ART
}

\author{
(C) Vyacheslav A. Berkovskiy, Natalya A. Leonova, Larisa A. Tronina \\ Stavropol State Pedagogical University, Stavropol, Russian Federation \\ science-almanac@mail.ru
}

The field of ethnography is extremely broad, nevertheless, conditionally it is possible to distinguish two classes of objects of this science depending on its attitude to its material. The first class of such objects includes spontaneous ethnic processes or processes which have taken place in the past, and the second class includes ethnic processes which by their nature, involve a certain social regulation. In the first case, the task of ethnography consists in scientific study of facts and maximum complete reconstruction of the past ethnic cultures, in the second its task is not exhausted by research and theoretical reconstruction of the activities of ethnic groups, although, of course, the creation of theories is the first task for any science. In society, ethnography is increasingly faced with the task of exercising, within the limits of its competence, a sociotechnological, regulatory function. Increasing the efficiency of carrying out socio-technological or already socio-pedagogical tasks by ethnography significantly actualizes the problem of further clarification and enrichment of its framework of categories and concepts, of mobilization for this purpose of theoretical and cognitive means of other disciplines (social psychology, literature, linguistics).

Key words: personality, spiritual life, cultural fund of the people, ethnic identity, culture of ethnic groups, cultural values, sociocultural memory, ethnic history.

\section{[В.А. Берковский, Н.А. Леонова, Л.А. Тронина Исторические формы этнического самосознания в контексте развития современного искусства]}

Область этнографии чрезвычайно широка, тем не менее можно условно выделить два класса объектов этой науки в зависимости от ее отношения к своему материалу. К первому классу таких объектов относятся стихийно протекающие этнические процессы или же процессы, имевшие место в прошлом, ко второму - этнические процессы, предполагающие в силу своей природы определенное общественное регулирование. В первом случае задача этнографии заключается в научном изучении фактов и максимально полной реконструкции прошлых этнических культур, во втором ее задача не исчерпывается исследованием и теоретическим воссозданием деятельности этносов, хотя, разумеется, создание теорий является для всякой науки ее первейшей задачей. В обществе перед этнографией все более настоятельно встает задача осуществлять в пределах своей компетенции социальнотехнологическую, регулятивную функцию. Повышение эффективности выполнения социальнотехнологических или - уже - социально-педагогических задач этнографией значительно актуализирует проблему дальнейшего уточнения и обогащения ее категориально-понятийного аппарата, мобилизации с этой целью теоретико-познавательных средств иных дисциплин (социальной психологии, литературоведения, лингвистики).

Ключевые слова: личность, духовная жизнь, культурный фронд народа, этническое самосознание, культура этносов, культурные ценности, социокультурная память, этническая история.

Vyacheslav A. Berkovskiy - Ph.D. in Sociology, Associate Professor, Stavropol State Pedagogical Institute, Stavropol, Russian Federation.

Natalya A. Leonova - Ph.D. in History, Associate Professor, Stavropol State Pedagogical Institute, Stavropol, Russian Federation.

Larisa A. Tronina - Ph.D. (Advanced Doctorate) in Philosophy, Associate Professor, Stavropol State Pedagogical Institute, Stavropol, Russian Federation.

Берковский Вячеслав Александрович - кандидат социологических наук, доцент, Ставропольский государственный педагогический институт, г. Ставрополь, Российская Федерация.

Леонова Наталья Александровна - кандидат исторических наук, доцент, Ставропольский государственный педагогический институт, г. Ставрополь, Российская Федерация. 
Тронина Лариса Анатольевна - доктор фрилософфских наук, доцент, Ставропольский государственный педагогический институт, г. Ставрополь, Российская Федерация.

If to agree that the ultimate goal of educational impact on the personality is the maximum identification and improvement of the identity (for scientific sociology it is an axiom), then it is also necessary to recognize that the uniqueness of the personality is connected, in a deep way, with history and culture of the people which generated it, and it is especially determined by the degree of internationality of native culture and the way of life of native ethnos, "... by the forms of spiritual and practical development of the world, which express the valuable attitude of the person towards the reality" [4, pp. 9-12]. Therefore, the most important social and pedagogical means of disclosure of a unique originality of the individual is its spiritual guiding on the ways of centuries-old progressive forward ascension of mankind to the modern achievements of culture. The developed identity can be created mainly in the conditions of ethnos with the developed international traditions on the basis of familiarizing with ethnic and world culture.

Ethnography has a sufficient stock of empirical and theoretical material showing the significant social potential of the ethnic components of culture. In addition, there is a lot of data collected not only by ethnographers, but also by sociologists, cultural scientists, workers of mass communication means, and according to the data practice (and theory) of human education does not use all the internal possibilities of ethnic culture, in particular of ethnic history, naturally changing in historical time [3, pp. 45-49].

Ethnic processes in society are diverse. They are influenced by complex interactions of natural and regulated processes, ancient and new components of culture, namelessmass (anonymous) and author's forms of art. All problems of national ethnography are directly or indirectly connected with social reality, spiritual life of society. The question of cultural and educational functions of nameless and mass forms of folk art, both ancient and contemporary, has become particularly acute. Whether these forms are included in the tradition of society, what are the laws of such inclusion, these questions concern not only ethnographers and not only specialists. The positive answer to the first question is undeniable for the ethnographer, and as for the second, it is possible to state the existence of a problematic situation.

The cultural fund of modern ethnic groups consists of both the results of mass folk art and of the creations of professional cultural figures. This well-known provision should be cited here, as the laws of inheritance, broadcasting, understanding and learning of cultural values are different for these subsystems. The cultural fund of the people is a historical phenomenon. In various formations, the values of ethnic culture have increased spontaneously. The historism of folk art is extremely complex, contradictory. The results of this are incompletness of historical memory of ethnos, displacement of time layers in it, known non critical thinking to various ideological phenomena.

The cultural fund of modern ethnic groups is a typologically different entity. The important feature of its development is the fact that not only new material and spiritual values are being increased, but also cultural heritage is being developed on an increasing scale. Life provides a lot of evidence that without serious consequences it is impossible to limit the validity of the principle: history belongs to the people. The return to modern ethnos of their past takes place in various ways. Ethnography has considerable scientific possibilities for reconstruction of lost fragments and whole types of culture and for creation of certain cognitive prerequisites for their return to the fund of culture of the people. In modern conditions, it is science and professional art that act as the most powerful channels for the creation of secondary (in the ethnographic sense of the word) layers of folk culture. 
Ethnic identity is a synthetic component of the cultural fund. Y. V. Bromley and V. I. Kozlov define this phenomenon as self-awareness of the members of the ethnic group as focusing ideas about the commonality of the territory (native land), language (native language), distinctive features of culture and psyche, as well as commonality of origin and historical fate of the people included in it.

The most important task of ethnography is to deepen our ideas about the laws of functioning and development of the fund of culture of ethnos. This is important for the first class of objects of its subject area, but this is even more important for the second, because the lag in scientific support of the regulation of ethnocultural and ethnic processes in society results in tangible losses in many spheres of social life.

Nameless and mass and professional and author's forms of culture are united by the fact that in a certain part (namely updated for modern generations of ethnos) they form cultural fund of the people. Their community in the specified sense allows to use advancement of studying of one form for knowledge of laws of development of another.

In the field of literary criticism works on studying of regularities of life of the work of art during various historical periods, of the nature of understanding of the literary work in other historical and cultural eras, in other ethnic environments were developed some time ago. Such referral of researches got the name of historical and functional. By way of illustration it is possible to give the following example.

Analyzing the historical fates of such a masterpiece of ancient Russian literature as "Life of the protopop Avvakum, written by him", it is possible to reach the following conclusion. Historical and cultural study of ancient Russian literature may prove promising for the development of national-patriotic and cultural traditions of the native olden time and contribute to further work on the introduction of outstanding monuments into the compound of cultural values of modern times. Religious beliefs are also relevant, which "emphasizing the influence on the philosopher of theological ideas..." [5, pp. 29-31], note "the influence of Orthodoxy on the formation and design of Russian culture" [9, pp. 39-44].

Various elements of maintenance of a monument are differently broadcast and interpreted by various generations of ethnos, otherwise, they are included into its cultural fund in peculiar way. In this regard it is necessary to distinguish the substantial and ideological and esthetic parts (functions) of a monument. If the first is very removed from the modern person in most cases, then the situation with the second function is different. Substantial and ideological function of a monument is caused by the main, but passing signs of a feudal and medieval formation (religious and symbolical, moral and didactic, historiosophical and informative, and first of all feudal and political). The value of esthetic function of an ancient monument does not weaken eventually, but, on the contrary, increases. Thus, the monument is included into the cultural fund of ethnos, undergoing certain changes. The main for an era of creation features of a monument stop being those during the subsequent eras. In historical memory of the people the cultural monument continues to live already in other semantic understanding, there is strengthening of its emotional and esthetic, national and psychological and social and patriotic functions providing "... education of the positive attitude towards cultural distinctions" [2, pp. 7-10].

It is safe to assume that here before us there is an essential feature of the development of the cultural fund of ethnos. The certain phenomenon of culture (work of folklore, rite, author's writing), which goes through its time (era of its creation) and develops features of ethnocultural experience of the people, continues its existence as an aesthetic phenomenon with pronounced ethnic marking.

Aestheticization and glorification of the past of its people is a historically early form of social (in this case only ethnocentric) memory. Thus, in form, the early spiritual works of ethnos are artistic (it should not be forgotten that it is a special artistic, which does not yet know the opposition to rationality and in an undeveloped form contains this future 
rationality). What is their content?

The man began the spiritual mastering the reality with a holistic reflection of the external-natural and own bodily-natural world. The mythological creativity of the peoples of all continents confirms this situation strongly. So, the early types of ethnic consciousness can be characterized as artistic in form and worldly, if so allowed, in content. Pictures of the world of ethnos contain both general and specific features. Ethnography provided extensive evidence of diversity and commonality of perceptions of the world of different ethnic groups. Thus, science solves the fundamental problem of studying the historical and cultural prerequisites of ideology and practice of public consciousness.

As noted above, the theoretical and methodological arsenal of ethnography contains the category of ethnic identity. Let's talk about the ratio of this category to the concept of the ethnic picture of the world.

The scope of the category of ethnic identity is of a world-encompassing nature and in this sense it is consistent with the concept of the ethnic picture of the world. But there is also a difference between them. The first is born of the need to reflect the dynamics of ethnic processes, subjective moments of ethno-contact relations. The second applies more in cases when it is necessary to emphasize the objective nature of some historical form of ethnic consciousness, which allows to identify the best qualities of the individual [7, pp. 15-18] in the context of "shaping a new social reality" [8, pp. 64-68] related to "the public consciousness... of common cultural norms and values" [6, pp. 6-12].

The synthetic concept of the picture of the world is attracting the increasing attention of representatives of many sciences these days. Concepts of scientific, artistic and language picture of the world are developed actively. By introducing the concept of an ethnic picture of the world, we are able to solve our own problems, based on the methodological potential of a new interdisciplinary scientific direction.

Issues related to the language picture of the world are of considerable interest for ethnography. Lexical, ideographic, frequency dictionaries of the Russian language, which have been published in recent years, allow to study certain aspects of verbal forms of ethnic consciousness not only qualitatively, but also in structural-quantitative terms.

Ethnos theory specifically addresses the nature and boundaries of a certain dependence of people's thinking and behavior on the type of language. In this case, there is no need to give a detailed assessment of Sapir-Whorf's linguistic relativity hypothesis. What is important for us is that modern researchers see a certain rational kernel in SapirWhorf's assumptions, leaning toward the idea that there are indeed differences in languages which neither determined nor explained by differences of non-linguistic realities. Language is related to reality not only because it has a list of names of its constituent elements, but also because the very structure of language, in the most general sense - the rules of formation of some expressions from others, also reflects human perceptions of the world.

Differences between languages are most evident in the structure of vocabulary. The number of words characterizing personality varies greatly in different languages. The analysis shows what sense sets form the noted quantitative differences, but the fact of such differences only signals the presence of a problem situation.

The ethnic uniqueness of language is largely embedded in the secondary nomination system, a metaphor. It is true that the spirit of the people expresses itself most deeply in metaphors, they most likely convey the difference in thinking and feeling of races and tribes.

The difficult diversity of the world's ethnic pictures constitutes the cultural wealth of mankind. Diverse in detail, these pictures are united in the essential foundations of human being. In fact, the ancient layers of the world pictures' representations of peoples reveal significant similarities that unite the spiritual life of ethnic groups. For example, the so- 
called permanent symbols have developed at the early stage of human history and they are close and accessible to the understanding of people of different nationalities and different eras. This includes images-symbols of earth, water, sky, mother and child, light and darkness, life and death, war and peace.

The language picture of the world is evolving with the development of ethnos and it is conditioned by this development. Just as three main types of ethnic identity are identified: ethnic groups of pre-class societies, ethnic groups of class societies, and ethnic groups of the same type of society, three types of pictures of the world of ethnic groups can be assumed. The picture of the world of modern ethnos is qualitatively different from the previous ones, it contains the principles of dialectical-materialistic worldview, it develops in the context of scientific worldview, it is fundamentally oriented to include the best artistic and aesthetic achievements of all previous stages of development, it determines "the need of consideration... of dispositions of social structures" [1, pp. 168-177].

The cultural fund of ethnos is not without structure. Its structure is closely related to its genesis and development. In turn, both the structure and the historical development of ethnic culture significantly influence the nature of its inclusion into the context of the spiritual life of modern ethnic groups. The allocation in the traditional and professional culture of the people of the ethnic picture of the world, of its historical types, is an attempt to penetrate the internal structure of the sociocultural memory of the people, to find out the laws of the introduction of new generations to the treasure of folk knowledge, skills, language and other forms of mastering the world.

Living or experiencing an ethnic history by an individual is a complex multidimensional process. In its cognitive form, it is a generalized learning of ethnic and world culture. Species, forms of such generalization can be different. The specific type of integrated perception of historical reality is the ethnic picture of the world and its language form of existence.

\section{Лumepamypa}

1. Бакланова О.А. Бакланов И.С. Современная российская социальность в контексте социального конструкционизма // Вопросы социальной теории. 2015. Т. 7. № 1-2. С. 168-177.

2. Говердовская Е.В. Особенности проектирования образовательного пространства высшей школы в поликультурном регионе // Экономические и гуманитарные исследования регионов. 2014. № 4. С. 7-10.

3. Гончаров В.Н. Социальный аспект религии в контексте развития первобытного общества // Гуманитарные и социально-экономические науки. 2016. № 2(87). С. 45-49.

4. Ерохин А.М. Религия и искусство в системе культуры // European Social Science Journal. 2014. № 7-2 (46). С. 9-12.

5. Камалова О.Н. «Созерцание» в фрилософрско-культурологических построениях И. Ильина // Гуманитарные и социально-экономические науки. 2012. № 6. С. 2931.

6. Колосова О.Ю. Духовная сфера: универсализм и самобытность // European Social Science Journal. 2012. №11-2(27). С. 6-12.

7. Лобейко Ю.А. Социально-педагогический аспект активности личности в системе общественного развития // Экономические и гуманитарные исследования регионов. 2015. №1. С. 15-18.

8. Лукьянов Г.И. Трансформационные процессы в современном российском обществе как отражение динамики новой социальной реальности // Экономические и гуманитарные исследования регионов. 2017. №4. С. 64-68. 
9. Матяш Т.П., Несмеянов Е.Е. Православный тип культуры: идея и реальность // Гуманитарные и социально-экономические науки. 2015. № 3 (82). С. 39-44.

\section{References}

1. Baklanova O.A. Baklanov I.S. Sovremennaia rossiiskaia sotsialnost v kontekste sotsialnogo konstruktsionizma. Voprosy sotsialnoi teorii. [Modern Russian sociality in the context of social constructionism. Issues of social theory]. 2015. V. 7. No. 1-2. pp. 168-177 (in Russian).

2. Goverdovskaya E. V. Osobennosti proektirovaniia obrazovatelnogo prostranstva vysshei shkoly v polikulturnom regione. Ekonomicheskie i gumanitarnye issledovaniia regionov. [Peculiarities of Design of Higher School Educational Space in Multicultural Region. Economic and humanitarian studies of regions]. 2014. No. 4. pp. 7-10 (in Russian).

3. Goncharov V. N. Sotsialnyi aspekt religii v kontekste razvitia pervobytnogo obshchestva. Gumanitarnye i sotsialno-ekonomicheskie nauki. [Social aspect of religion in the context of the development of primitive society. Humanitarian and socioeconomic sciences]. 2016. No. 2(87). pp. 45-49 (in Russian).

4. Erokhin A.M. Religiia $\mathrm{i}$ iskusstvo $\mathrm{v}$ sisteme kultury. [Religion and Art in the Culture System]. European Social Science Journal. 2014. No. 7-2 (46). pp. 9-12 (in Russian).

5. Kamalova O. N. "Sozertsanie v filosofsko-kulturologicheskikh postroeniiakh I. Ilina. Gumanitarnye i sotsialno-ekonomicheskie nauki. ["Contemplation" in the philosophical and cultural constructions of I. Ilina. Humanitarian and socio-economic sciences]. 2012. No. 6. pp. 29-31 (in Russian).

6. Kolosova O.Yu. Dukhovnaia sfera: universalizm i samobytnost. [Spiritual Sphere: Universalism and Identity]. European Social Science Journal. 2012. No. 11-2(27). pp. 6-12 (in Russian).

7. Lobeiko Yu.A. Sotsialno-pedagogicheskii aspekt aktivnosti lichnosti v sisteme obshchestvennogo razvitiia. Ekonomicheskie i gumanitarnye issledovaniia regionov. [Social and pedagogical aspect of the activity of the individual in the system of social development. Economic and humanitarian studies of regions]. 2015. No. 1. pp. 15-18 (in Russian).

8. Lukianov G.I. Transformatsionnye protsessy v sovremennom rossiiskom obshchestve kak otrazhenie dinamiki novoi sotsialnoi realnosti. Ekonomicheskie i gumanitarnye issledovaniia regionov. [Transformational processes in modern Russian society as a reflection of the dynamics of the new social reality. Economic and humanitarian studies of regions]. 2017. No. 4. pp. 64-68 (in Russian).

9. Matiash T.P., Nesmeyanov E.E. Pravoslavnyi tip kultury: ideia i realnost. Gumanitarnye i sotsialno-ekonomicheskie nauki. [Orthodox type of culture: idea and reality. Humanitarian and socio-economic sciences]. 2015. No. 3 (82). pp. 39-44 (in Russian). 